УДК 004.773:339.138]:640.43

DOI: 10.31866/2616-7654.8.2021.247591

\section{ІНФОРМАЦІЙНА СКЛАДОВА БРЕНДИНГУ: КЕЙС ЗАКЛАДІВ ГРОМАДСЬКОГО ХАРЧУВАННЯ}

Радомир Щербаков, пошукач кафедри інформаційних технологій Київського національного університету культури і мистецтв (Київ, Україна)

e-mail:restorad@gmail.com ORCID: 0000-0002-0090-8305

Зважаючи на широке проникнення інтернет-технологій у маркетингові практики, однією з яких є брендинг, прискорення інтернетизації бізнесових процесів внаслідок пандемії COVID-19 і вимоги соціального дистанціювання, постійне вдосконалення і розширення переліку інтернет-інструментів брендингу, актуалізується завдання визначення і обгрунтування ролі та складових інформаційного компонента брендингу. Вирішенню цього завдання на прикладі вітчизняних кейсів закладів громадського харчування присвячена пропонована стаття.

Застосування під час дослідження комплексу наукових методів, зокрема оглядовоаналітичного, системного, кейс-методу, методу індукції, та опрацювання публікацій у фахових і профільних виданнях, матеріалів 3МI, контенту веб-сайтів і соціальних медіа дали змогу виокремити в інформаційній складовій брендингу закладів громадського харчування технологічний та змістовний компоненти.

До змістовного компонента віднесено:

1) розробку концепції або «легенди» бренду - його позиціонування в конкурентному середовищі, яке визначає ключові меседжі, спрямовані на забезпечення впізнаваності та ідентифікації бренду;

2) візуально-вербальне вираження узгодженої концепції бренду:

- візуальна інформація - логотип, дизайн приміщення, уніформа персоналу, дизайн сайту, представництв закладу в соціальних мережах;

- вербальний компонент - слоган, меню, стилістика і зміст повідомлень.

До технологічного компонента інформаційної складової брендингу віднесено ті програмно-технологічні інструменти, за допомогою яких відбуваються поширення інформації про бренд та комунікація із клієнтським середовищем: офіційні веб-сайти закладів, їх представництва в соціальних мережах, мобільні застосунки, месенджери, інтернет-реклама.

Доведено, що ефективний брендинг передбачає гармонійне поєднання змістовного і технологічного компонентів. Акцент на технології і збої у змістовному компоненті закладають ризики репутаційних і фінансових втрат підприємства.

Ключові слова: брендинг, інформаційні технології, інтернет-технології, заклади громадського харчування. 


\section{ВСТУП}

Сьогодні інформаційні технології стали буденним атрибутом усіх суспільних практик, проте пошуки оптимальних шляхів їх використання не втрачають своєї актуальності. Це пов’язано як із постійним вдосконаленням самих технологій, появою нових програмних продуктів і сервісів, так і зі змінами умов, у яких перебувають суб’єкти їх використання.

Протягом перших десятиріч XXI ст. ми стали свідками не лише поширення електронних технологій, а й інтернет- і мобільних технологій, хмарних сервісів.

Пандемія COVID-19 і вимога соціального дистанціювання лише прискорили інтернетизацію різних суспільних процесів. Зокрема, це стосується функціонування закладів громадського харчування, багато з яких змушені були перебудувати свою роботу «на винос» і впровадити систему онлайнових замовлень. Успішний досвід використання інформаційних технологій закладами громадського харчування заслуговує на вивчення та широке впровадження.

Метою пропонованої розвідки є обгрунтування значення та складових інформаційного компонента брендингу на прикладі кейсів закладів громадського харчування.

\section{ТЕОРЕТИЧНЕ ПІДГРУНТЯ}

Ефективне використання інформаційних технологій для вирішення завдань маркетингу перебуває у фокусі наукової уваги багатьох вітчизняних і зарубіжних науковців, які, проте, не розглядають його в аспекті закладів громадського харчування.

Так, обгрунтування впливу інформаційних технологій на досягнення маркетингових завдань підприємства здійснено Ю. Байрактутаном, Б. Арсланом, Е. Кайгисиз та Є. Друікою (Bayraktutan et al., 2009), які аналізували функціонування моделей маркетингових інформаційних систем; використання офіційних веб-сайтів і представництв у соціальних медіа як інструментів інтернет-маркетингу малими та середніми підприємствами було розглянуто М. Сіндху, Н. Коррі та Н. М. Юліанті (Sindhu et al., 2019); вплив інформаційних технологій на маркетингову функцію підприємства на основі досвіду 204 фахівців із маркетингу середніх і великих компаній Ірландії розкрито М. Брейді, М. Сареном та Н. Цокасом (Brady et al., 1999).

Вітчизняні дослідники І. Болотіна, О. Шаповал і К. Савкова (2017) проаналізували особливості використання інтернет-технологій та інформаційних систем підприємства у брендингу і запропонували розглядати інфраструктуру інформаційних систем підприємства (сукупність комп’ютерного, комунікаційного мережевого обладнання, операційних прикладних систем, програмного забезпечення та систем управління базами даних, що використовуються на підприємстві) як платформу для ефективного використання ресурсів інтернету, інтернет-технологій та здійснення успішного брендингу.

О. Небилиця і К. Тімонін (2014), Н. Безрукова та Л. Тимченко (2014) зосередились на розкритті значення і специфіки інтернет-брендингу в сучасній маркетинговій діяльності підприємств і обгрунтували інтернет-брендинг як ефективний інструмент посилення конкурентоспроможності компанії в умовах глобальної конкуренції. Науковцями було визначено ключові вимоги до веб-сайту як важливого інстру- 
менту інтернет-брендингу, окреслено переваги просування бренду в соціальних мережах, визначено типові помилки інтернет-брендингу, серед яких:

- нехтування потребою проведення маркетингових досліджень;

- відсутність концепції бренду;

- погане опрацювання елементів візуальної ідентифікації;

- недостатня рекламна активність;

- однобічність повідомлень;

- зловживання використанням зонтичних брендів;

- відсутність вимірювань (Небилиця \& Тімонін, с. 15).

Р. Окрепкий і Д. Гаргула (2012), зі свого боку, обгрунтували вимоги до вебсайту як інструменту просування інтернет-бренду на електронному ринку, серед яких визначили:

- зовнішній вигляд і функціональність сайту, його відповідність очікуванням, сформованим у результаті рекламного впливу;

- виразність і повноту подання інформації про фірму та іï продукцію на сайті;

- якість обслуговування (швидкість обробки замовлень, швидкість реакції на звернення);

- надійність роботи системи, яка забезпечує функціонування сайту і надання послуг;

- унікальність як самого рішення, так і видів сервісу, що пропонуються (наприклад, порівняння характеристик товарів, одержуваних переваг);

- реальну користь для користувачів (с. 209).

О. Міцура та М. Хижняк (2012) розкрили переваги онлайнового репутаційного менеджменту (ORM) порівняно із традиційним, виокремили і розглянули такі компоненти ORM:

- $\quad$ SMM ORM - побудова репутації в соціальних медіа;

- $\quad$ SERM ORM - правильна робота з відгуками та коментарями у блогах, на форумах, тематичних сайтах та створення за допомогою цього відповідної репутації;

- $\quad$ SEO ORM - просування в мережі інтернет, а точніше в пошукових системах (наприклад, Google, Yandex, Meta) потрібних для побудови правильної репутації документів, які мають потрапити на першу сторінку пошукової видачі;

- Crisis ORM - робота з «урятування» репутації під час кризових ситуацій, нападу конкурентів, інформаційної війни та ін.;

- Public ORM - робота зі 3MI: написання статей, участь у певних онлайншоу та інтерв’ю, що сприятимуть формуванню іміджу компанії та укріпленню її репутації (с. 126).

М. Маранчак (2021) запропонував доповнити вказаний компонентний перелік ORM інструментами месенджер-маркетингу як напряму управління онлайнрепутацією компанії:

- MRM (Messenger Reputation Management) - побудова репутації в месенджерах, що передбачає роботу з відгуками, коментарями та іншими видами аудіо та текстових повідомлень на каналах, у групах і чатах із використанням зовнішніх та вбудованих ботів, публічних акаунтів, бізнес-профілів, розсилок та інструментів НМ (прихованого маркетингу); 
- IMRM (Instant Messaging Reputation Management) - захист та підтримка репутації в системах миттєвого обміну повідомленнями, які включають в себе месенджери, програми онлайн-консультанти та програми-клієнти, що можуть передавати текстові повідомлення, звукові сигнали, зображення, відео (с. 121).

Згаданими авторами за допомогою застосування різних методів доводяться переваги використання в маркетинговій діяльності інтернет-технологій, їх сприяння персоналізації продуктів і послуг, більшому охопленню аудиторії, зростанню ефективності комунікаційної взаємодії між підприємством і споживачами тощо. Проте специфіка використання інформаційного компонента в маркетинговій діяльності, зокрема для просування бренду, розглядається ними лише побіжно. Сьогодні з огляду на проникнення інтернет-технологій вже не стоїть питання, чи потрібно їх використовувати або які саме інтернет-інструменти можна використовувати для вирішення завдань маркетингу і брендингу як однієї 3 його цілей, водночас актуалізується завдання визначення, як саме використовувати такі інструменти, з’ясування структури інформаційної складової брендингу, співвідношення в ній змістовного і технологічного компонентів.

\section{МЕТОДИ І МАТЕРІАЛИ}

Результати дослідження грунтуються на використанні комплексу наукових методів, зокрема оглядово-аналітичного, системного, кейс-методу, методу індукції. Оглядово-аналітичний метод було застосовано під час опрацювання фахової і профільної літератури та визначення теоретичного підгрунтя дослідження, системний метод виявився ефективним під час розгляду компонентної структури інформаційної складової брендингу, кейс-метод було використано під час вивчення окремих прикладів використання інтернет-інструментів та інформаційних технологій у брендингу закладів громадського харчування, застосування методу індукції дало змогу провести узагальнення і зробити висновок стосовно інформаційної складової брендингу для закладів громадського харчування в цілому.

Джерельну основу дослідження склали публікації у фахових і профільних виданнях, матеріали ЗМІ, контент веб-сайтів і соціальних медіа. Для аналізу було відібрано три найкращі станом на жовтень 2021 р. за рейтингом TripAdvisor pecторани Києва ("Musafir", "Мама Манана", "China Ма"), а також найбільш відомий і успішний ресторан «Холдингу емоцій !FEST» «Криївка» (м. Львів) і ресторан «київської кухні» «За двома зайцями» (м. Київ). Усі заклади позиціонуються як сімейні ресторани, їх середні чеки приблизно однакові (200-500 грн).

\section{РЕЗУЛЬТАТИ ДОСЛІДЖЕННЯ}

Інформаційно-комунікаційна система функціонування будь-якого суб’єка бізнес-процесу складається із внутрішнього (корпоративного) і зовнішнього контурів, обидва 3 яких є важливими для життєздатності компанії.

Внутрішня комунікація забезпечує весь комплекс виробничих процесів, а їі оперативність, коректність, злагодженість визначають у підсумку гнучкість системи, її здатність швидко адаптуватись до нових зовнішніх умов. До внутрішньої системи комунікації може бути віднесена також комунікація із тими партнерами, які є необхідними для виробництва певних продуктів та/або послуг. 
Зовнішній контур інформаційно-комунікаційної системи підприємства складається із двох векторів: вхідного і вихідного. Вхідний вектор забезпечує зворотний зв’язок із користувацькою аудиторією і дає змогу визначати ефективність діяльності підприємства у досягненні поставлених цілей. Інформаційне наповнення вхідного вектора забезпечується прямими зверненнями користувачів, результатами маркетингових досліджень, а також інформацією, отриманою шляхом моніторингу інформаційного простору (як реального, так і віртуального) стосовно згадувань компанії, її продуктів та послуг. І якщо позитивні згадування підтверджують правильність ухвалених рішень і дій, то у разі негативних постає завдання швидкого коригування ситуації і поширення в інформаційному просторі повідомлень, спрямованих на нейтралізацію або мінімізацію негативних наслідків кризової ситуації. Невдала антикризова політика та ігнорування потреби додаткової інформаційної кампанії, спрямованої на виправлення ситуації, створює ризики репутаційних і фінансових втрат. Для закладів громадського харчування налагодження ефективного функціонування вхідного вектора зовнішнього контуру інформаційно-комунікаційної системи підприємства набуває особливого значення з огляду на специфіку їх діяльності, пов'язану з термінами придатності продуктів харчування і безпечністю їжі для здоров’я споживачів, а також щільним спілкуванням працівників із клієнтами під час обслуговування.

Ілюстративним прикладом невдалої кризової комунікації стала ситуація, яка склалася 2016 р. навколо ресторанів відомого львівського «Холдингу емоцій !FEST», коли в соціальних медіа поширилась інформація стосовно отруєння неякісними продуктами багатьох відвідувачів у їдальні УКУ від компанії Fest Lokal і відмовою !FEST компенсувати завдану шкоду (Зайцев, 2017). Відповідну публікацію Б. Лозицького прокоментували 900 осіб (серед яких чимало блогерів із тисячами послідовників у мережі) (Зайцев, 2017). Як бачимо, в умовах горизонтальної мережі інтернет-комунікацій інформація про будь-який негативний випадок може набути вірусного поширення і завдати шкоди бренду, тому важливими $€$ своєчасне визначення такої інформації та оперативне реагування і поширення інформації нейтралізуючого характеру.

Вихідний вектор відповідає за донесення до користувацької аудиторії основних меседжів компанії, її власного бачення себе і свого місця на ринку. Саме вихідний вектор є найвиразнішим проявом маркетингової стратегії підприємства і відповідає за формування його позитивного іміджу і просування бренду (брендинг).

Останнє включає визначення назви бренду та його впізнаваності, конструювання концепції («легенди») бренду, інформаційну підтримку функціонування концепції бренду через створені продукти і послуги, розробку відповідної айдентики. Усі перелічені елементи формують змістовний компонент брендингу. Проте для успішної маркетингової кампанії важливим є, також, технологічний компонент - шляхи і підходи до поширення інформації про бренд, його продукти і послуги. Коли ідеться про просування компанії в інтернет-середовищі, говорять про інтернет-брендинг.

Для успішної інформаційної політики компанії необхідним є гармонійне поєднання її змістовного і технологічного компонентів. 
Сьогодні ефективними технологічними інструментами інтернет-брендингу $€$ інтернет-сайти компаній (Sindhu et al., 2019, Безрукова \& Тимченко, 2014, Окрепкий \& Гаргула, 2012), їх сторінки і сторінки їх працівників у соціальних медіа (Безрукова \& Тимченко, 2014, Міцура \& Хижняк, 2012), мобільні застосунки, месенджери (Маранчак, 2021), інтернет-реклама. Ці інструменти є корисними для формування позитивного іміджу і позиціонування компанії як сучасної, відкритої, клієнтоорієнтованої. Водночас нерозуміння значення змістовного компонента або нехтування ним здатне завдати компанії репутаційної шкоди і збитків. I чим більшою є залежність компанії від інтернет-інструментів у просуванні бренду, тим відчутнішими можуть стати негативні наслідки невдалих змістовних рішень.

Яскравим прикладом останнього стала ситуація із власницею української торговельної марки веганської їжі Yаro Ю. Приваловою, яка в жовтні 2021 р. розмістила в соціальній мережі Instagram своє фото з Красної площі в Москві і відповіла анекдотом про бандерівців на негативні коментарі під цією публікацією ("Rozetka відмовилася", 2021, "Компании разрывают контракты", 2021). Цілий ряд споживачів продукції бренду та його партнерів у підсумку відмовились від співпраці з ним, про що зазначив у відповідній публікації громадський і політичний діяч С. Стерненко (див. рис. 1).

Влучно і чітко прокоментувала ситуацію співзасновниця видавництва Creative Women Publishing Орнелла Остапенко: «Як виглядає знищення бренду?

- виставити фото з Красної площі в Москві;

- відповісти на негатив у коментарях анекдотом, що відверто націлений образити українців;

- $\quad$ привернути ще більше уваги своїм мовчанням після провокації. Тепер ми знаємо, що власниця бренду донька Василя Козака, голови Сокирянської районної ради від Аграрної партії України, та невістка Кернеса;

- $\quad$ iï ж аудиторія піднімає скандал у соціальних мережах, після чого продукти бренду зникають із маркетплейсів типу Розетки та інтернет-магазину Сільпо (не дивно, бо її продукт має високу ціну та націлений на здорове харчування - аудиторія відповідно активна);

- і останнє: після тривалої паузи дуже нещиро вибачитись, зберігши презирство до своєї аудиторії в тексті, додати шаблонний прапор України та виставити себе жертвою травлі» (Ostapenko, 2021).

Отже, ефективність інтернет-комунікації визначається не лише привабливістю від початку створеного інтернет-іміджу, широким використанням інтернет-інструментів брендингу, але і тими смислами, які поширюються за допомогою згаданих інструментів.

Особливо виразно змістовний компонент вихідного вектора зовнішнього контуру інформаційно-комунікаційної системи підприємства проявився у брендингу закладів громадського харчування холдингу !FEST, що сприяло не лише зростанню їхньої привабливості, а й перетворенню на одні з найвідоміших атракцій Львова.

Однією з найбільш популярних серед згаданої мережі є ресторація «Криївка» 3 унікальною концепцією (Brand Story або «легендою» бренду), яка сприяє іії чіткій ідентифікації і створює специфічне емоційно-історичне тло. У докарантинні часи, за інформацією ЗМІ, відвідуваність ресторану становила в середньому до 
Український журнал з бібліотекознавства та інформаційних наук. Випуск 8 (2021) Ukrainian Journal on Library and Information Science. Issue 8 (2021)

1 млн на рік. Примітно, що 2021 р. заклад увійшов до Книги рекордів України (категорія «Державність»), адже його швейцар, п. Микола Панченко, який працює тут із перших днів відкриття упродовж 14 років, відповів «Героям слава!»на гасло «Слава Україні!» 1,2 мільйона разів. Результати зафіксували за підрахунками, згідно зі статистикою закладу про відвідуваність (Рой, 2021).

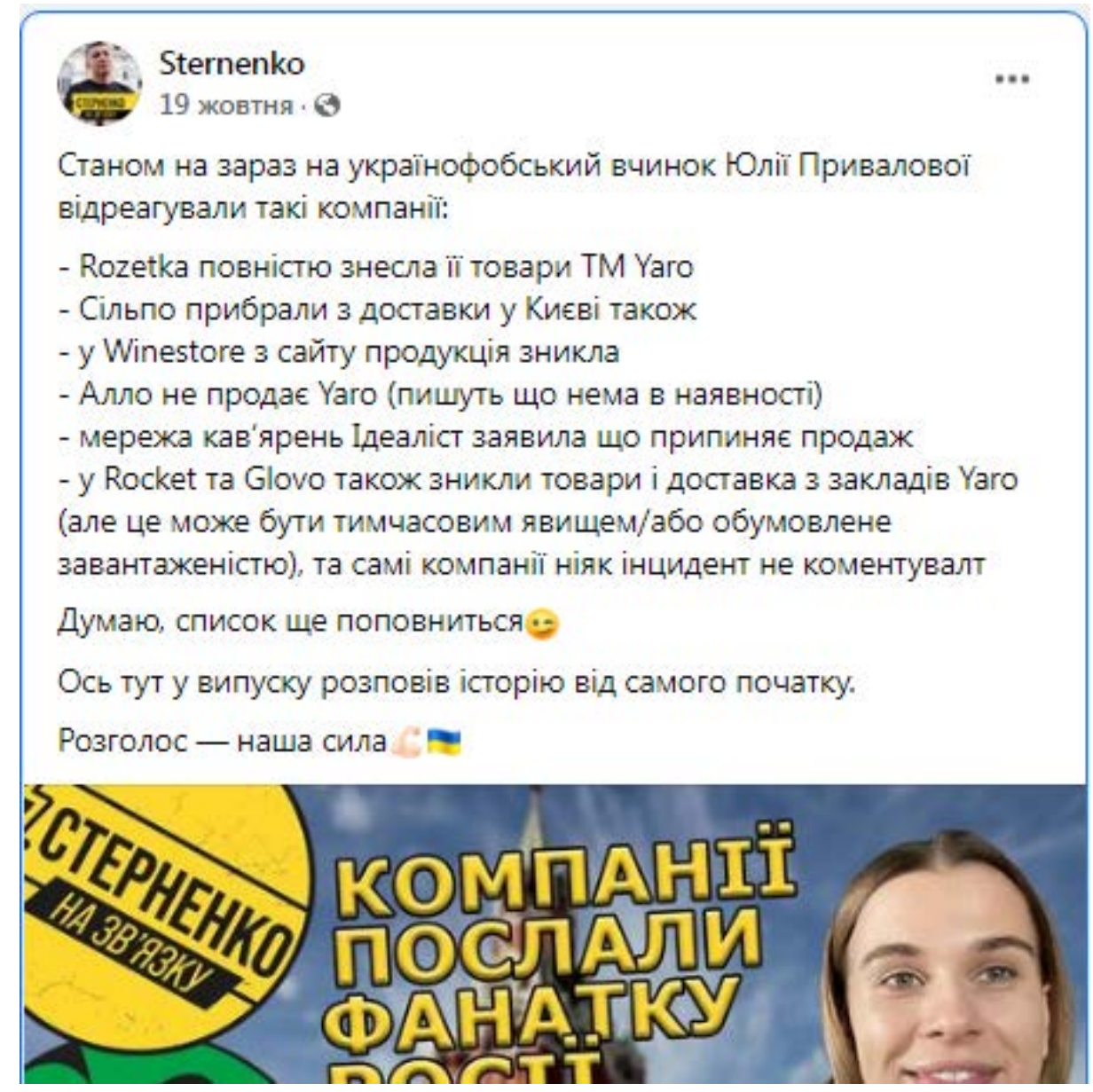

Puc. 1. Публікація С. Стерненка в соціальній мережі Facebook від 19 жовтня 2021 р. Джерело: https://cutt.ly/MTGDx80.

Назва локації та її дизайн є прямими відсилками до подій Другої світової війни, а саме руху опору Української повстанської армії (УПА). Академічний тлумачний словник української мови визначає поняття «криївка» як захисток; схованку ("Криївка", 1973, с. 344). Примітно в цьому контексті, що заклад не має зовнішньої рекламної вивіски. Інтер'єр локації цілком відповідає обраній концепції і виконаний у стилі повстанського схрону, із грубими стінами і меблями, військовими атрибутами і плакатами (див. рис. 2). 

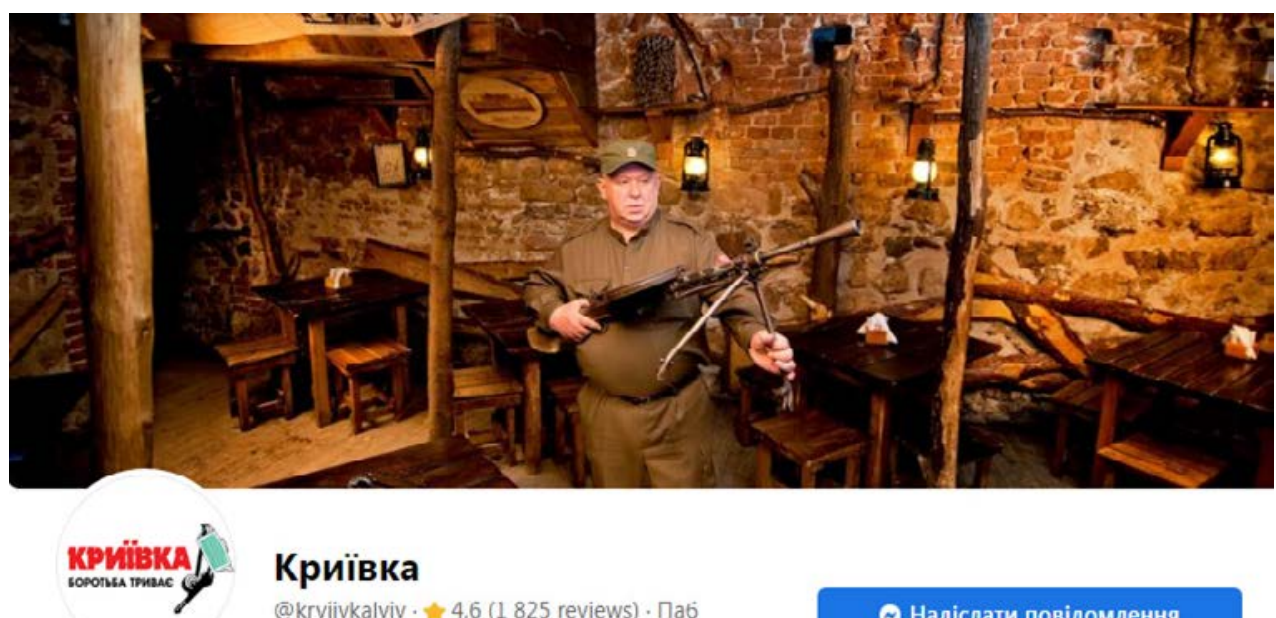

Криївка

@kryjivkalviv · 4.6 ( 1825 reviews) · Пa6

Puс. 2. Інтер’єр ресторану «Криївка» з обкладинки офіційного представництва закладу в мережі Facebook. Джерело: https://www.facebook.com/kryjivkalviv/.

Окремою органічно поєднаною із загальною концепцією закладу атракцією стала комунікація під час входу до ресторану (обмін паролем), яка від початку створює відповідний настрій і емоційний фон, перетворюючи процес споживання їжі на пригоду через відчуття причетності до групи «своїх», які мають доступ до таємниці, секрету.

Надалі в загальний концепт органічно інтегруються меню ресторану і комунікація з персоналом, яка відбувається в дусі військової романтики. Назви страв на кшталт пательня «Сита дивізія», «Вечеря лісового гауляйтера», оселедець «Балтійська допомога», борщ червоний «Перше причастя героя» тощо перетворюють вивчення меню на цікаву розвагу. У підсумку створюється специфічний комунікаційний простір не споживання, а співучасті. Причому на відміну від травматичного емоційного тла обговорення теми УПА в ЗМІ та науковій літературі, у «Криївці» дискурс УПА набуває виразного позитивного емоційного забарвлення.

Тема боротьби продовжується через відповідну інформаційну політику офіційних представництв ресторану в соціальних мережах і демонструє пріоритет концепту навіть перед вичерпністю інформування. Зокрема, розділ «Додаткова інформація» представництва ресторану у Facebook, який починається з гасла «Боротьба триває!», визначає розташування закладу як «десь на площі Ринок» та інформує про те, що він $є$ «останньою криївкою УПА, що залишилась із часів Другої світової і до наших днів. Живе під гаслом «Боротьба триває!» (Криївка, 2021). Навіть електронна пошта ресторану не дисонує із загальною концепцією: borotba. tryvaje@kryjivka.com.ua.

Інтернет-представництва закладу в соціальних мережах вдало поєднують візуальний і вербальний компоненти комунікації і оригінально адаптують «леген- 
ду» бренду до реалій карантинних обмежень сьогодення. Зокрема, до логотипу було додано захисну медичну маску (див. рис. 3).

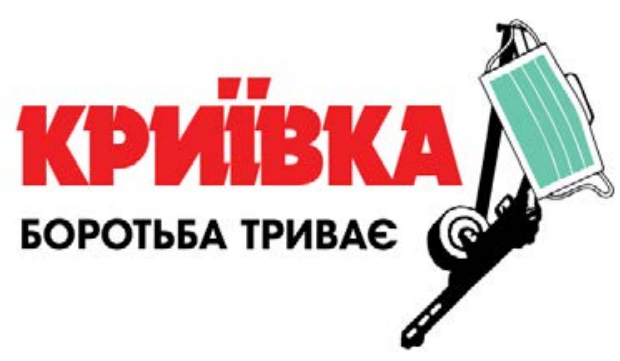

Puc. 3. Зображення захисної медичної маски на логотипі ресторану «Криївка». Джерело: https://cutt.ly/ZTHh1z0.

Стилістика повідомлень також витримана в дусі повстанських листівок. Кожна публікація починається з гасла «Слава Україні!» і містить інформацію, викладену максимально наближеною до «легенди» мовою. Ілюстративним у цьому контексті є повідомлення про можливість замовлень і доставки страв: «Слава Україні! Головний провід Криївки вживає всіх необхідних заходів для запобігання поширенню тої коронавірусної зарази.

Якби бракувало вдома провізії (готової їжі чи продуктів), то пишіть FEST доставка, вони там мають багато різного і смачного.

Бережіть себе і мийте руки!

Боротьба триває!» (Криївка, 2020). У представленому контексті боротьба стосується вже не стільки визвольних змагань народу України, скільки боротьби з коронавірусною інфекцією.

Представництва закладу в соціальних мережах також реалізують функцію інформування і зворотного зв'язку із клієнтами, кожен коментар яких отримує відповідь. На іншомовні коментарі відповідь надається англійською мовою, проте все одно починається з гасла «Слава Україні!» ("Glory to Ukraine!"). Зазвичай оновлення новинної стрічки відбувається 2-4 рази на місяць і стосуються як функціонування закладу (нові страви в меню, поновлення роботи після карантинних обмежень тощо), так і різних визначних дат і подій, цікавих сторінок історії, пов'язаних із повстанським рухом та боротьбою за незалежність України.

Станом на кінець листопада 2021 р. рейтинг ресторану «Криївка» за відгуками 1825 користувачів на офіційному представництві закладу у Facebook (засноване 29 червня 2009 р.) становив 4,6 із 5, публікації в мережі активно позначаються вподобайками (окремі публікації містять понад 500 вподобайок), поширюються і коментуються. На цей час офіційне представництво ресторану «Криївка»в мережі Facebook налічувало 20866 тих, хто вподобав сторінку, та 49296 тих, хто стежить за нею.

Подібний принцип відповідності інформаційної політики закладу обраній Brand Story простежується, також, у найпопулярніших за рейтингом TripAdvisor київських рестораціях «Musafir», «Мама Манана», «China Ма», які позиціонуються 
як заклади національної кухні, що, власне, становить основу їх Brand Story - острівці татарського Криму, привітної Грузії («Твоя Грузія у центрі Києва») та екзотичного Китаю в Україні, - а також ресторану «За двома зайцями», найближчого за концепцією до «Криївки». При цьому «Musafir» i «Мама Манана» посилюють «легенду» завдяки особистісному виміру: перший був відомим закладом кримського Бахчисарая, тож після анексії Криму родині власників довелося змінити локацію на Київ, другий - завдяки образу втіленої гостинності «Мами Манани», яка «рада бачити вас на своїй кухні» (Мама Манана, 2021a) (примітно при цьому, що заклади «Мама Манана» і «CHINA MA» належать одній власниці).

Обраним закладами концепціям відповідають дизайн їх інтер’єрів та меню, хоча сайти виглядають доволі аскетично. Винятком $є$ веб-сайт «За двома зайцями», який окрім необхідної інформації, містить також відсилку до самої «легенди» - однойменної комедійної п’єси Михайла Старицького (рубрика сайту «Про нас»), а також інформацію стосовно відомих відвідувачів ресторану - акторів і співаків.

Прагнення дотримуватися Brand Story повною мірою стосується і стилістики комунікації та меседжів закладів. Так, веб-сайт «Мама Манана» (http:// mamamanana.com.ua/), який позиціонується як ресторан грузинської кухні, звертається на веб-сайті до клієнтів просто так, як це зробила б рідна людина, «Сонечко!», а своїх працівників називає «зайченятами»: «Сонечко! Ми запустили новий сайт. Але не все буває ідеальним у цьому світі, тому можливі технічні проблеми із замовленнями. Якщо ми не телефонуємо з приводу замовлення, то набери моїх зайченяток, щоб впевнитися, що все добре». Подібні публікації в дусі маминих порад розміщуються офіційним представництвом закладу в мережі Facebook: «Шоб мати, чого не мав, потрібно робити те, чого ніколи не робив. Починай вже зараз і не відкладай на потім. Наприклад, на кулінарних уроках від племінників Манани» (Мама Манана, 2021).

Мережеві публікації «За двома зайцями» витримані у стилістиці героя твору Голохвастова з характерними «Бонжур! Моє сердце розпалілося, как щіпци...», «в головє такой водевіль, аж мерсі...» тощо (Ресторація «За двома зайцями», 2021).

Найскладніше дотримуватись легенди ресторану китайської їжі «China Ma», то адже китайська культура в Україні не є широко відомою, проте певна стилізація і звернення до китайських традицій під час популяризації специфічних китайських страв, які можна замовити і скуштувати в ресторані, присутні.

Щодо закладу «Musafir», то його власники зробили акцент на інтернет-просування ще в кримський період роботи ресторану - були створені відповідні співтовариства в соціальних мережах, де публікувались новини з життя закладу, відстежувались відгуки і коментарі. Особлива увага приділялась рейтингу на інтернет-ресурсі TripAdvisor (Черныш, 2017).

Ілюстративною $є$ статистика інтернет-представництв згаданих ресторанів станом на кінець жовтня 2021 р. (див. табл. 1).

Як можна бачити із представлених у таблиці результатів, бренд «Криївка», 3 найдовшою історією, сьогодні навіть за найнижчої активності в мережі (заклад навіть не має власного веб-сайту) має найбільш широку і активну аудиторію, що засвідчує вдалий вибір його позиціювання: українська кухня з історичним патріотичним колоритом і акцентом на розважальність виявилась затребуваним про- 
Український журнал з бібліотекознавства та інформаційних наук. Випуск 8 (2021) Ukrainian Journal on Library and Information Science. Issue 8 (2021)

дуктом. «Musafir» i «Мама Манана» започаткували свої представництва в мережі відносно недавно, з 2015 р., і реалізують схожу інформаційну політику. Утім, хоча за кількістю отриманих відгуків позиції «Мама Манана» вдвічі кращі, представництво цього закладу в декілька разів поступається «Musafir» у системній активності аудиторії, що може свідчити про відсутність сталого клієнтського ядра, яке увиразнюється у випадку «Musafir».

Таблиця 1.

\section{Статистика активності інтернет-представництв ресторанів у мережі Facebook станом на кінець жовтня 2021 p.}

\begin{tabular}{lccccc}
\hline & $\begin{array}{c}\text { «China } \\
\text { Ма» }\end{array}$ & «Musafir» & $\begin{array}{c}\text { «Мама } \\
\text { Манана» }\end{array}$ & $\begin{array}{c}\text { «За двома } \\
\text { зайцями }\end{array}$ & «Криївка» \\
\hline $\begin{array}{l}\text { час заснування пред- } \\
\text { ставництва }\end{array}$ & 2019 p. & 2015 p. & 2015 p. & 2012 р. & 2009 р. \\
\hline рейтинг / к-ть відгуків & $4,9 / 257$ & $4,8 / 566$ & $4,7 / 1029$ & $4,8 / 213$ & $4,6 / 1822$ \\
\hline $\begin{array}{l}\text { кількість тих, хто вподо- } \\
\text { бав / стежить }\end{array}$ & $\begin{array}{c}3158 / \\
3387\end{array}$ & $\begin{array}{c}12110 / \\
13284\end{array}$ & $\begin{array}{c}12177 / \\
12720\end{array}$ & $5485 / 5566$ & $\begin{array}{c}20866 / \\
49296\end{array}$ \\
\hline $\begin{array}{l}\text { середня оновлюваність } \\
\text { (кількість публікацій на }\end{array}$ & $4-9$ & $\begin{array}{c}8 \text { (літо), } \\
1-2 \text { (осінь) }\end{array}$ & $\begin{array}{c}10 \text { (літо), } \\
\text { місяць) }\end{array}$ & $4-10$ & $2-4$ \\
$\begin{array}{l}\text { реакція на па публікації } \\
\text { (середня/найбільша) }\end{array}$ & $7-9 / 24$ & $164 / 413$ & $20 / 68$ & $10-17 / 42$ & $154 / 561$ \\
\hline
\end{tabular}

У цьому контексті варто позитивно відзначити намагання «Мами Манани» залишатися з клієнтами на зв’язку через запуск мобільного застосунку, який дає змогу переглянути детальне меню з описанням інгредієнтів кожної страви, самостійно сформувати замовлення, його доставку або самовивіз, інформує про акції, спеціальні пропозиції, а також новинки меню.

Третє місце ділять між собою заклади «China Мa» $\mathrm{i}$ «З двома зайцями». I якщо у разі «China Ма» відносно низькі статистичні показники можуть пояснюватися специфічністю китайської кухні та нетривалим періодом функціонування, який, до того ж, припав на час карантинних обмежень, то у разі заснованогоо ще 2000 p. «За двома зайцями», вочевидь, причини інші. Не виключено, що в середовищі міленіалів концепція «міщанського кітчу» Києва поч. ХХ ст. вже не знаходить бажаного відгуку. Водночас акцент на емоцію і відповідність «легенді», добротне меню, якому, проте, порівняно 3 «Криївкою,» бракує концептуальних назв, демократичні ціни, помножені на вдале розташування, станом на жовтень 2021 р. утримують заклад у двадцятці кращих за відгуками інтернет-ресурсу TripAdvisor. Утім, за умови збереження рестораном нинішньої інформаційно-комунікаційної політики, можна прогнозувати його поступове відставання від «China Ма», особливо враховуючи, що останній запустив спеціальний мобільний застосунок і в такий спосіб розширив інструментарій охоплення клієнтської аудиторії (див. рис. 4).

Як бачимо, інформаційно-комунікаційна політика найбільш популярних закладів громадського харчування за кейсами успішних ресторанів Києва і Львова $€$ прикладом вдалого поєднання змістовного та технологічного компонентів зовнішнього контуру інформаційно-комунікаційної системи підприємства 
і працює на зміцнення бренду. Усі розглянуті ресторани відрізняються чіткими концепціями і позиціюванням на ринку громадського харчування, мають свої веб-сайти (за винятком «Криївки») і представництва в соціальних мережах Facebook та Instagram, відстежують відгуки і коментарі користувачів і оперативно реагують на них.

\section{China Ma}

iThinkers Їжа та напої

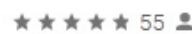

\section{CHINAMA}

$16+$

\section{(•) Цей додаток доступний для вашого пристрою}

目 додати в список бажань

\section{Установити}
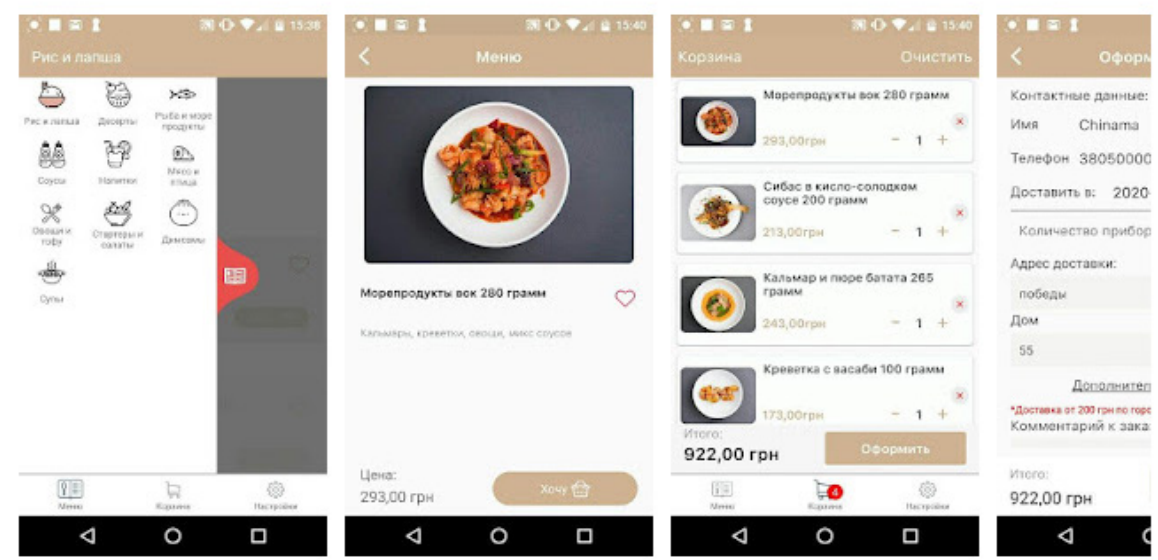

Puc. 4. Інтерфейс мобільного застосунку «China Ма».

Джерело: https://play.google.com/store/apps/details?id=com.ithinkers.chinama\&hl=uk.

\section{ВИСНОВКИ}

Інформаційна складова брендингу закладу громадського харчування складається $з$ технологічного та змістовного компонентів.

До змістовного компонента відносяться:

1) розробка концепції або «легенди» бренду - його позиціонування в конкурентному середовищі, яке визначає ключові меседжі, спрямовані на забезпечення впізнаваності та ідентифікації бренду;

2) візуально-вербальне вираження узгодженої концепції бренду:

- візуальна інформація - логотип, дизайн приміщення, уніформа персоналу, дизайн сайту, представництв закладу в соціальних мережах;

- вербальний компонент - слоган, меню, стилістика і зміст повідомлень. 
До технологічного компонента інформаційної складової брендингу відносяться ті програмно-технологічні інструменти, за допомогою яких відбуваються поширення інформації про бренд та комунікація із клієнтським середовищем: офіційні веб-сайти закладів, їх представництва в соціальних мережах, мобільні застосунки, месенджери, інтернет-реклама.

Ефективний брендинг передбачає гармонійне поєднання змістовного і технологічного компонентів. Акцент на технології і збої у змістовному компоненті закладають ризики репутаційних і фінансових втрат підприємства.

\section{СПИСОК ПОСИЛАНЬ}

Безрукова Н. В., Тимченко Л. В. Брендинг в мережі Інтернет як засіб глобальної маркетингової комунікації. Ефективна економіка. 2014. № 12. URL: https://cutt.ly/hTKKgIX (дата звернення: 25.10.2021).

Болотіна І. М., Шаповал О. Ф., Савкова К. Г. Брендинг: особливості використання Інтернет-технологій та інформаційних систем підприємства. Формування ринкових відносин в Україні : зб. наук. праць. 2017. Вип. 1 (188). С. 72-75.

Зайцев I. Помилка резидента: Найяскравіші помилки українських SMM-фахівців. The Association of Retailers of Ukraine. 18 березня 2017. URL: https://rau.ua/dosvid/oshibkarezidenta-smm/ (дата звернення: 25.10.2021).

Компании разрывают контракты с невесткой Кернеса, пошутившей о бандеровцах на фоне Кремля. Фокус. 19 октября 2021. URL: http://surl.li/augpj (дата обращения: 25.10.2021).

Криївка. Словник української мови. Київ, 1973. Т. 4. С. 344. URL: http://sum.in.ua/s/kryjivka (дата звернення: 25.10.2021).

Криївка. Додаткова інформація. Facebook. 2021. URL: https://cutt.ly/9TKXzOe (дата звернення: 25.10.2021).

Криївка. Боротьба триває. Facebook. 2020. URL: https://cutt.ly/TTHkLYv/ (дата звернення: 25.10.2021).

Мама Манана. Главная. Facebook. 10 вересня 2021. URL: https://www.facebook.com/ mamamanana.kiev (дата звернення: 25.10.2021).

Маранчак М. Месенджер-маркетинг як напрям управління онлайн-репутацією (ORM) компанії. Український журнал з бібліотекознавства та інформаційних наук. 2021. Вип. 7. C. $115-126$.

Міцура О. О., Хижняк М. О. Управління онлайн-репутацією: теоретичні засади та методичні підходи. Маркетинг і менеджмент інновацій. 2012. № 4. C. 121-127. URL: https:// cutt.ly/KbKWlqm (дата звернення: 25.10.2021).

Небилиця О. А., Тімонін К. О. Сучасні особливості інтернет-брендингу в Україні. Економіка розвитку (Economics of Development). 2014. № 1 (69). С. 12-17.

Окрепкий, Р. Б., Гаргула Д. В. Механізм просування інтернет-бренду на електронному ринку. Інноваційна економіка. 2012. № 1. С. 208-212.

Остапенко О. Про комунікативний кейс бренду YARO. Facebook. 19 жовтня 2021. URL: https:// cutt.ly/4TGGzt2 (дата звернення: 25.10.2021).

Ресторація «За двома зайцями». Главная. Facebook. 2021. URL: https:/www.facebook.com/ Chasing.two.Hares/?ref=page_internal (дата звернення: 25.10.2021).

Рой В. Понад мільйон разів «Слава Україні»: швейцар «Криївки» встановив рекорд. Львівський портал. 31 серпня 2021. URL: https://cutt.ly/tTXsZUa (дата звернення: 25.10.2021). 
Черныш В. Оккупанты закрыли ресторан семьи Мустафы Джемилева в Крыму, но дети воссоздали его в Киеве. История «Мусафира». MC Today. 6 сентября 2017. URL: https:// cutt.ly/xTXS7Nm (дата обращения: 25.10.2021).

Rozetka відмовилася від співпраці. Реакція компаній та соцмереж на жарт власниці ТМ Yaro про бандерівців. НВ Україна. 19 жовтня 2021. URL: https://cutt.ly/ITGHCmw (дата звернення: 25.10.2021).

Bayraktutan Y., Arslan B., Kaygisiz E. G., Druica E. The Effects of Information Technologies in Marketing. Lex et Scientia. 2009. Vol. 15, № 2, P. 190-196(7). URL: https://cutt.ly/qTKv2xP (accessed: 25.10.2021).

Brady M., Saren M., Tzokas, N. Information Technology and its Relationship to Marketing and Marketing Relationships. Proceedings of The 15'1'Annual IMP Conference / McLoughlin, Da mien, and C. Horan (eds.). University College. Dublin, 1999. URL: https://cutt.ly/KTKEmin (accessed: 25.10.2021).

Sindhu M., Korry N., Yulianti N. M. Information technology adoption on digital marketing communication channel. International Journal of Social Sciences and Humanities. 2019. Vol. 3, Iss. 2. P. 95-104. https://doi.org/10.29332/ijssh.v3n2.297 (accessed: 25.10.2021).

\section{REFERENCES}

Bezrukova, N. V., \& Tymchenko, L. V. (2014). Brendynh v merezhi Internet yak zasib hlobalnoi marketynhovoi komunikatsii [Branding on the Internet as a Means of Global Marketing Communication.]. Efektyvna ekonomika, 12, https://cutt.ly/hTKKgIX [in Ukrainian].

Bolotina, I. M., Shapoval, O. F., \& Savkova, K. H. (2017). Brendynh: osoblyvosti vykorystannia Internet-tekhnolohii ta informatsiinykh system pidpryiemstva [Branding: fFeatures of Using Internet Technologies and Information Systems of the Enterprise]. Market Relations Development in Ukraine, 1(188 ), 72-75 [in Ukrainian].

Zaitsev, I. (2017, March 18). Pomylka rezydenta: Naiiaskravishi pomylky ukrainskykh SMM-fakhivtsiv [The Brightest Mistakes of Ukrainian SMM-Specialists]. The Association of Retailers of Ukraine. https://rau.ua/dosvid/oshibka-rezidenta-smm/ [in Ukrainian].

Fokus. (2021, October 19). Kompanii razryivayut kontraktyi s nevestkoy Kernesa, poshutivshey o banderovtsah na fone Kremlya [Companies break contracts with Kernes's daughter-inlaw, who joked about Bandera people against the background of the Kremlin]. https://cutt. ly/1TLew2N [in Russian].

Slovnyk ukrainskoi movy. (1973). Kryivka [Hide and seek]. In Slovnyk ukrainskoi movy [Dictionary of the Ukrainian Language] (Vol. 4, p. 344). http://sum.in.ua/s/kryjivka [in Ukrainian].

Kryivka. (2021). Dodatkova informatsiia [Additional Information]. Facebook. https://cutt. ly/9TKXzOe [in Ukrainian].

Kryivka. (2020). Borotba tryvaie [The struggle continues]. Facebook. https://cutt.ly/TTHkLYv/ [in Ukrainian].

Mama Manana. (2021b, September 10). Hlavnaia [Home]. Facebook. https://www.facebook.com/ mamamanana.kiev [in Ukrainian].

Maranchak, M. (2021). Mesendzher-marketynh yak napriam upravlinnia onlain-reputatsiieiu (ORM) kompanii [Messenger Marketing as a Direction of the Company Online Reputation Management (ORM)]. Ukrainian Journal on Library and Information Science, 7, 115-126 [in Ukrainian].

Mitsura, O. O., \& Khyzhniak, M. O. (2012). Upravlinnia onlain-reputatsiieiu: teoretychni zasady ta metodychni pidkhody [Online Reputation Management: Theoretical Principles and Methodological Approaches]. Marketing and Management of Innovations, 4, 121-127. https:// cutt.ly/KbKWlqm [in Ukrainian]. 
Nebylytsia, O. A., \& Timonin, K. O. (2014). Suchasni osoblyvosti internet-brendynhu v Ukraini [Modern Features of Internet Branding in Ukraine]. Economics of Development, 1(69), 12-17 [in Ukrainian].

Okrepkyi, R.B., \& Harhula,D.V.(2012).Mekhanizm prosuvannia internet-brendu na elektronnomu rynku [The Mechanism of Internet Brand Promotion in the Electronic Market]. Innovative Economy, 1, 208-212 [in Ukrainian].

Ostapenko, O. (2021, October 19). Pro komunikatyvnyi keis brendu YARO [About the Communicative Case of the YARO Brand]. Facebook. https://cutt.ly/4TGGzt2 [in Ukrainian].

Restoratsiia "Za dvoma zaitsiamy". (2021). Hlavnaia [Home]. Facebook. https://www.facebook. com/Chasing.two.Hares/?ref=page_internal [in Ukrainian].

Roi, V. (2021, August 31). Ponad milion raziv "Slava Ukraini": shveitsar "Kryivky" vstanovyv record [More than a million times "Glory to Ukraine": the doorman of "Kryivka" set a record]. Lvivskyi portal. https://cutt.ly/tTXsZUa [in Ukrainian].

Chernyish, V. (2017, September 6). Okkupantyi zakryili restoran semi Mustafyi Dzhemileva v Kryimu, no deti vossozdali ego $v$ Kieve. Istoriya "Musafira" [The occupiers closed the restaurant of Mustafa Dzhemilev's family in the Crimea, but the children recreated it in Kiev. The story of Musafir]. MC Today. https://cutt.ly/xTXS7Nm [in Russian].

NV Ukraina. (2021, October 19). Rozetka vidmovylasia vid spivpratsi. Reaktsiia kompanii ta sotsmerezh na zhart vlasnytsi TM Yaro pro banderivtsiv [Rozetka refused to cooperate. The reaction of companies and social networks to the joke of the owner of TM Yaro about Bandera people]. https://cutt.ly/ITGHCmw [in Ukrainian].

Bayraktutan, Y., Arslan, B., Kaygisiz, E. G., \& Druica E. (2009). The Effects of Information Technologies in Marketing. Lex et Scientia, 15(2), 190-196(7). https://cutt.ly/qTKv2xP [in English].

Brady, M., Saren, M., \& Tzokas, N. (1999). Information Technology and its Relationship to Marketing and Marketing Relationships. In McLoughlin, Da mien, and C. Horan (eds.). Proceedings of The 15'1' Annual IMP Conference, University College, Dublin. https://cutt. ly/KTKEmin [in English].

Sindhu, M., Korry, N., \& Yulianti, N. M. (2019). Information technology adoption on digital marketing communication channel. International Journal of Social Sciences and Humanities, 3(2), 95-104. https://doi.org/10.29332/ijssh.v3n2.297 [in English]. 
UDC 004.773:339.138]:640.43

\author{
Radomyr Shcherbakov, \\ Doctoral Candidate, \\ Information Technology Department, \\ Kyiv National University of Culture and Arts \\ (Kyiv, Ukraine) \\ e-mail:restorad@gmail.com \\ ORCID: 0000-0002-0090-8305
}

\title{
INFORMATION COMPONENT OF BRANDING: CASE OF PUBLIC CATERING INSTITUTIONS
}

Given the widespread penetration of Internet technology in marketing practices, one of which is branding, accelerating the internetization of business processes due to the COVID-19 pandemic and the requirements of social distancing, continuous improvement and expansion of online branding tools, the task of defining and justifying of the role of branding informational component becomes actual. The proposed article is devoted to solving this issue on the example of cases of catering establishments.

The application of a set of scientific methods, including review-analytical, system, casemethod, induction method, and processing of publications in professional and specialised publications, media materials, social media content, made it possible to distinguish technological and content components in the information dimension of catering establishments' branding.

The content component includes:

1) development of the concept or "legend" of the brand - its positioning in a competitive environment, which determines the key messages aimed at ensuring brand recognition and identification;

2) visual and verbal expression of the agreed concept of the brand:

- $\quad$ visual information - logo, room design, staff uniform, site design, representations in social networks;

- verbal component - slogan, menu, style and content of messages.

The technological component of the information dimension of branding includes those software and technology tools through which information is disseminated about the brand and communication with the customer environment: official websites of institutions, their representation in social networks, mobile applications, messengers, online advertising.

It is proved that effective branding involves a harmonious combination of content and technological components. The emphasis on technology and failures in the content component create risks of reputational and financial losses of the enterprise.

Keywords: branding, information technology, Internet technology, public catering establishments.

Стаття надійшла до редакції 08.11.2021 p. 